\title{
Multi-year record of atmospheric mercury at Dumont d'Urville, East Antarctic coast: continental outflow and oceanic influences
}

\author{
Hélène Angot ${ }^{1}$, Iris Dion ${ }^{1}$, Nicolas Vogel ${ }^{1}$, Michel Legrand ${ }^{1,2}$, Olivier Magand ${ }^{2,1}$, and Aurélien Dommergue ${ }^{1,2}$ \\ ${ }^{1}$ Univ. Grenoble Alpes, Laboratoire de Glaciologie et Géophysique de l'Environnement (LGGE), 38041 Grenoble, France \\ ${ }^{2}$ CNRS, Laboratoire de Glaciologie et Géophysique de l'Environnement (LGGE), 38041 Grenoble, France \\ Correspondence to: Aurélien Dommergue (aurelien.dommergue@univ-grenoble-alpes.fr)
}

Received: 23 March 2016 - Published in Atmos. Chem. Phys. Discuss.: 1 April 2016

Revised: 16 June 2016 - Accepted: 17 June 2016 - Published: 8 July 2016

\begin{abstract}
Under the framework of the Global Mercury Observation System (GMOS) project, a 3.5-year record of atmospheric gaseous elemental mercury $(\mathrm{Hg}(0))$ has been gathered at Dumont d'Urville (DDU, $66^{\circ} 40^{\prime} \mathrm{S}, 140^{\circ} 01^{\prime} \mathrm{E}, 43 \mathrm{~m}$ above sea level) on the East Antarctic coast. Additionally, surface snow samples were collected in February 2009 during a traverse between Concordia Station located on the East Antarctic plateau and DDU. The record of atmospheric $\mathrm{Hg}(0)$ at DDU reveals particularities that are not seen at other coastal sites: a gradual decrease of concentrations over the course of winter, and a daily maximum concentration around midday in summer. Additionally, total mercury concentrations in surface snow samples were particularly elevated near DDU (up to $194.4 \mathrm{ng} \mathrm{L}^{-1}$ ) as compared to measurements at other coastal Antarctic sites. These differences can be explained by the more frequent arrival of inland air masses at DDU than at other coastal sites. This confirms the influence of processes observed on the Antarctic plateau on the cycle of atmospheric mercury at a continental scale, especially in areas subject to recurrent katabatic winds. DDU is also influenced by oceanic air masses and our data suggest that the ocean plays a dual role on $\operatorname{Hg}(0)$ concentrations. The open ocean may represent a source of atmospheric $\mathrm{Hg}(0)$ in summer whereas the sea-ice surface may provide reactive halogens in spring that can oxidize $\operatorname{Hg}(0)$. This paper also discusses implications for coastal Antarctic ecosystems and for the cycle of atmospheric mercury in high southern latitudes.
\end{abstract}

\section{Introduction}

The Antarctic continent is one of the last near-pristine environments on Earth and still relatively unaffected by human activities. Except for pollutants released from Antarctic Research stations (e.g., Hale et al., 2008; Chen et al., 2015) and by marine and air-borne traffic (Shirsat and Graf, 2009), only the long-lived atmospheric contaminants reach this continent situated far from anthropogenic pollution sources. With an atmospheric lifetime on the order of 1 year (Lindberg et al., 2007), gaseous elemental mercury $(\operatorname{Hg}(0))$ is efficiently transported worldwide. $\operatorname{Hg}(0)$ is the most abundant form of mercury in the atmosphere (Lindberg and Stratton, 1998). It can be oxidized into highly reactive and water-soluble gaseous divalent species $(\mathrm{Hg}(\mathrm{II}))$ - that can bind to existing particles and form particulate mercury $(\operatorname{Hg}(\mathrm{p}))$ - leading to the deposition of reactive mercury onto various environmental surfaces through wet and dry processes (Lindqvist and Rodhe, 1985; Lin and Pehkonen, 1999). Upon deposition, $\mathrm{Hg}(\mathrm{II})$ can be reduced and reemitted back to the atmosphere as $\operatorname{Hg}(0)$ (Schroeder and Munthe, 1998). Assessing mercury deposition and reemission pathways remains difficult due to an insufficient understanding of the involved physical-chemical processes.

Only sparse measurements of atmospheric mercury have been performed in Antarctica and there are still many gaps in our understanding of its cycle at the scale of this vast continent $\left(\sim 14\right.$ million $\mathrm{km}^{2}$ ) (Dommergue et al., 2010). To date, observations were made over 1 year at the coastal site of Neumayer (NM, Ebinghaus et al., 2002; Temme et al., 2003) and during summer campaigns at Terra Nova Bay (TNB, Sprovieri et al., 2002) and McMurdo (MM, Brooks et al., 2008b). More recently, multi-year records have been ob- 


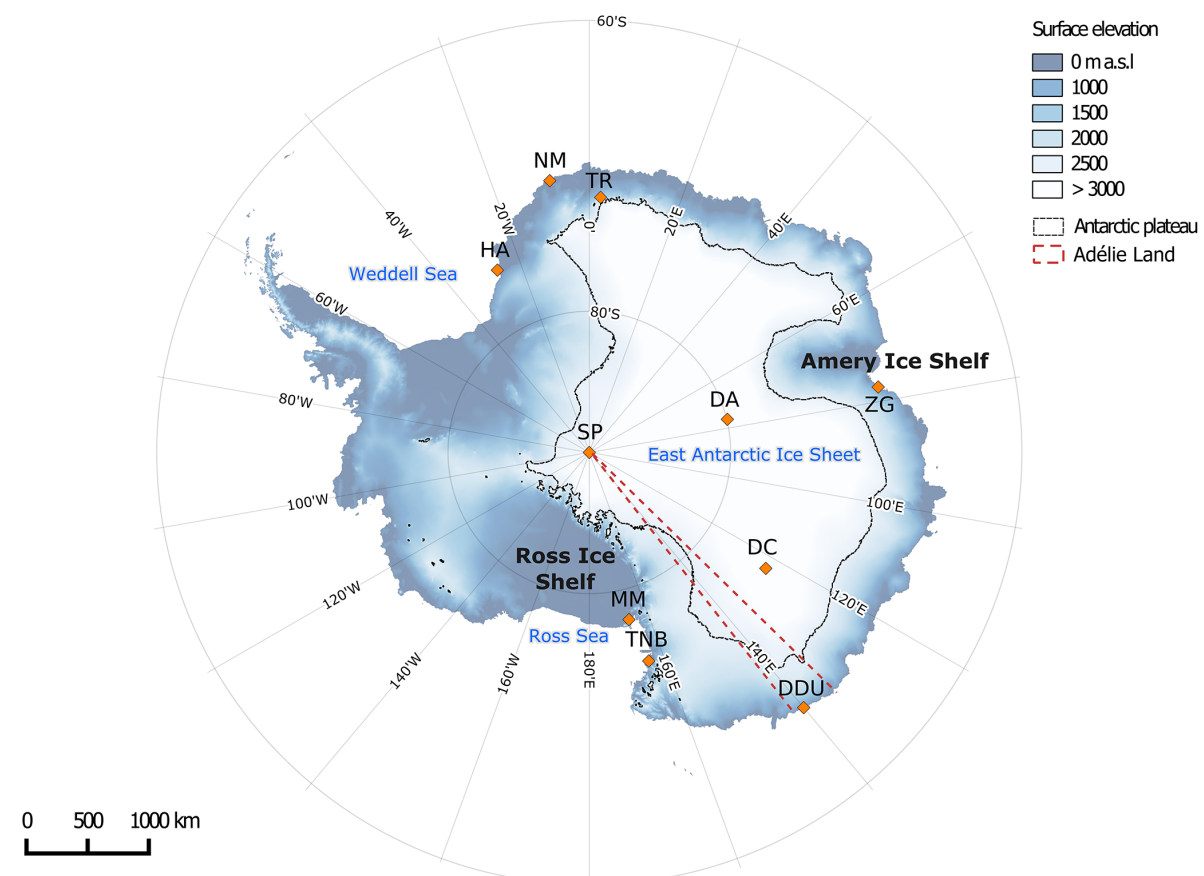

Figure 1. Map of Antarctica showing surface elevation (meters above sea level, ma.s.l.) and the position of various stations: Halley (HA), Neumayer (NM), Troll (TR), Zhongshan Station (ZG), Dome A (DA), South Pole Station (SP), Concordia Station (DC), Dumont d'Urville (DDU), McMurdo (MM), and Terra Nova Bay (TNB). The black line delimits the high altitude plateau ( $>2500 \mathrm{~m}$ a.s.1.), and the red dotted line Adélie Land (from 136 to $142^{\circ} \mathrm{E}$ ).

tained at Troll (TR) situated approximately $220 \mathrm{~km}$ from the coast at $1275 \mathrm{~m}$ a.s.l. (Pfaffhuber et al., 2012) and Concordia Station located at Dome C (denoted DC, 3220 m a.s.l.) (Angot et al., 2016). Under the framework of the GMOS project (Global Mercury Observation System, www.gmos.eu), atmospheric monitoring of $\mathrm{Hg}(0)$ has been implemented at $\mathrm{Du}-$ mont d'Urville (DDU) located in Adélie Land (Fig. 1) and we here report the obtained 3.5-year record of atmospheric $\mathrm{Hg}(0)$ that represents the first multi-year record of $\mathrm{Hg}(0)$ available for the East Antarctic coast. In this paper, the $\mathrm{Hg}(0)$ record from DDU is discussed in terms of influence of marine vs. inland air masses, and compared to records available at other coastal (NM, TNB, MM) or near-coastal (TR) stations. In parallel, total mercury was determined in surface snow samples collected during a traverse between DC and DDU in February 2009. These results provide new insight into the transport and deposition pathways of mercury species in East Antarctica.

\section{Experimental section}

\subsection{Sampling site and prevailing meteorological conditions}

From January 2012 to May 2015, $\mathrm{Hg}(0)$ measurements were performed at DDU station located on a small island (Ile des
Pétrels) about $1 \mathrm{~km}$ offshore from the Antarctic mainland. A detailed description of the sampling site ("Labo 3") has been given by Preunkert et al. (2013) while the climatology of this coastal station has been detailed by König-Langlo et al. (1998). The average surface air temperature ranges from $-1{ }^{\circ} \mathrm{C}$ in January to $-17^{\circ} \mathrm{C}$ in winter, with a mean annual temperature of $-12^{\circ} \mathrm{C}$. The annual mean surface wind speed is $10 \mathrm{~m} \mathrm{~s}^{-1}$, with no clear seasonal variations. Due to the strong katabatic effects, the most frequent surface wind direction is $120-160^{\circ} \mathrm{E}$.

\subsection{Methods}

\subsection{1 $\operatorname{Hg}(0)$ measurements}

$\mathrm{Hg}(0)$ measurements were performed using a Tekran 2537B (Tekran Inc., Toronto, Canada). The sampling resolution ranged from 10 to $15 \mathrm{~min}$ with a sampling flow rate of $1.0 \mathrm{~L} \mathrm{~min}^{-1}$. Concentrations are reported here as hourly averages and are expressed in nanograms per cubic meter at standard temperature and pressure $(273.15 \mathrm{~K}, 1013.25 \mathrm{hPa})$. Setting a $0.2 \mu \mathrm{m}$ PTFE filter and a $10 \mathrm{~m}$-long unheated sampling line on the front of the analyzer inlet, we assume that mainly $\mathrm{Hg}(0)$ (instead of total gaseous mercury, defined as the sum of gaseous mercury species) was efficiently collected and subsequently analyzed by the instrument (Steffen et al., 2002; Temme et al., 2003; Steffen et al., 2008). 
External calibrations were performed twice a year by manually injecting saturated mercury vapor taken from a temperature-controlled vessel, using a Tekran 2505 mercury vapor calibration unit and a Hamilton digital syringe, and following a strict procedure adapted from Dumarey et al. (1985). As described by Angot et al. (2014), fortnightly to monthly routine maintenance operations were performed. A software program was developed at the LGGE (Laboratoire de Glaciologie et Géophysique de l'Environnement) following quality control practice commonly applied in North American networks (Steffen et al., 2012). Based on various flagging criteria (Munthe et al., 2011; D’Amore et al., 2015), it enabled rapid data processing in order to produce clean time series of $\operatorname{Hg}(0)$. According to the instrument manual, the detection limit is $0.10 \mathrm{ng} \mathrm{m}^{-3}$ (Tekran, 2011).

\subsubsection{Snow sampling and analysis}

Eleven surface snow samples (the upper $3 \mathrm{~cm}$ ) were collected during a traverse between DC and DDU conducted in February 2009. As described by Dommergue et al. (2012), samples were collected using acid cleaned PTFE bottles and clean sampling procedures. After sampling, samples were stored in the dark at $-20^{\circ} \mathrm{C}$. Field blanks were made by opening and closing a bottle containing mercury-free distilled water. Total mercury $\left(\mathrm{Hg}_{\text {tot }}\right)$ in snow samples was analyzed using a Tekran Model 2600. $\mathrm{Hg}_{\text {tot }}$ includes species such as $\mathrm{HgCl}_{2}, \mathrm{Hg}(\mathrm{OH})_{2}, \mathrm{HgC}_{2} \mathrm{O}_{4}$, stable complexes such as $\mathrm{HgS}$ and $\mathrm{Hg}(\mathrm{II})$ bound to sulfur in humic compounds, or some organomercuric species (Lindqvist and Rodhe, 1985). The instrument was calibrated with the NIST SRM-3133 mercury standard. Quality assurance and quality control included the analysis of analytical blanks, replicates, and internal standards (reference waters for mercury: HG102-2 at $22 \mathrm{ng} \mathrm{L}^{-1}$ from Environment Canada). The limit of quantification - calculated as 10 times the standard deviation of a set of 3 analytical blanks - was $0.3 \mathrm{ng} \mathrm{L}^{-1}$ and the relative accuracy $\pm 8 \%$.

Surface snow samples collected during traverses may have limited spatial and temporal representativeness given the variability of chemical species deposition onto the snow surface, and the occurrence of either fresh snowfall or blowing snow. The (in)homogeneity of surface snow samples was investigated at MM by Brooks et al. (2008b). Surface $(3-5 \mathrm{~cm})$ snow samples were collected daily $(n=14)$ at different snow patches. $\mathrm{Hg}_{\text {tot }}$ concentrations averaged $67 \pm 21 \mathrm{ng} \mathrm{L}^{-1}$. This result indicates that the spatial and temporal representativeness of surface snow samples collected in Antarctica can be satisfactory and gives us confidence that spatial differences in $\mathrm{Hg}_{\text {tot }}$ concentrations reported in Sect. 3.2.2 are not due to samples inhomogeneity.

\subsubsection{Ancillary parameters}

$\mathrm{O}_{3}$ was continuously monitored with a UV absorption monitor (Thermo Electron Corporation model 49I, Franklin, Mas- sachusetts) (Legrand et al., 2009). Collected at 15-s intervals, the data are reported here as hourly averages.

Back trajectories were computed using the HYSPLIT (Hybrid Single-Particle Lagrangian Integrated Trajectory) model (Draxler and Rolph, 2013). Meteorological data from Global Data Assimilation Process (available at ftp://arlftp.arlhq. noaa.gov/pub/archives/gdas1) were used as input, and the model was run every hour in backward mode for 5 days at 0 , 200 , and $500 \mathrm{~m}$ above the model ground level. Three typical situations prevail at DDU: strong katabatic winds flowing out from the Antarctic ice sheet situated south of the station, pure marine air masses, or continental/marine mixed air masses with easterly winds due to the arrival near the site of lowpressure systems (König-Langlo et al., 1998). Oceanic origin was attributed to air masses having traveled at least 1 day over the ocean and less than 3 days out of 5 over the highaltitude Antarctic plateau. Conversely, plateau origin refers to air masses having traveled at least 3 days over the highaltitude Antarctic plateau and less than 1 day out of 5 over the ocean. Finally, mixed origin refers to air masses having traveled less than 1 and 3 days out of 5 over the ocean and the high-altitude Antarctic plateau, respectively. It should be noted that uncertainties associated with calculated backward trajectories arise from possible errors in input meteorological fields and numerical methods (Yu et al., 2009), and increase with time along the way (Stohl, 1998). According to Jaffe et al. (2005), back trajectories only give a general indication of the source region. Despite these limitations, back trajectories remained very similar at the three levels of altitude arrival at the site and we only use here those arriving at the model ground level. This method also gave consistent results with respect to the origin of various chemical species including $\mathrm{O}_{3}$ (Legrand et al., 2009), HCHO (Preunkert et al., 2013), $\mathrm{NO}_{2}$ (Grilli et al., 2013), and sea-salt aerosol (Legrand et al., 2016a).

\subsection{Local contamination}

Pollution plumes due to the station activities (e.g., combustion, vehicular exhaust) occasionally reached the sampling site. Such local pollution events can be easily identified for instance by the fast decrease of $\mathrm{O}_{3}$ or increase of $\mathrm{HCHO}$ mixing ratios (Legrand et al., 2009; Preunkert et al., 2013). We used a criterion based on wind direction and sudden drops of $\mathrm{O}_{3}$ mixing ratios to filter the raw data (i.e., collected at $5 \mathrm{~min}$ intervals) and discard $\mathrm{Hg}(0)$ data impacted by local pollution. $\operatorname{Raw} \mathrm{Hg}(0)$ data above $1.60 \mathrm{ng} \mathrm{m}^{-3}$, corresponding to the mean +3 standard deviation, obtained when the wind was blowing from $30^{\circ} \mathrm{W}$ to $70^{\circ} \mathrm{E}$ (i.e., the sector where main station activities are located), and accompanied by a drop of $\mathrm{O}_{3}$ were discarded from the data set. Using this criterion, only $0.1 \%$ of raw $\mathrm{Hg}(0)$ data was discarded, the $\mathrm{Hg}(0)$ record being very weakly impacted by pollution plumes. 


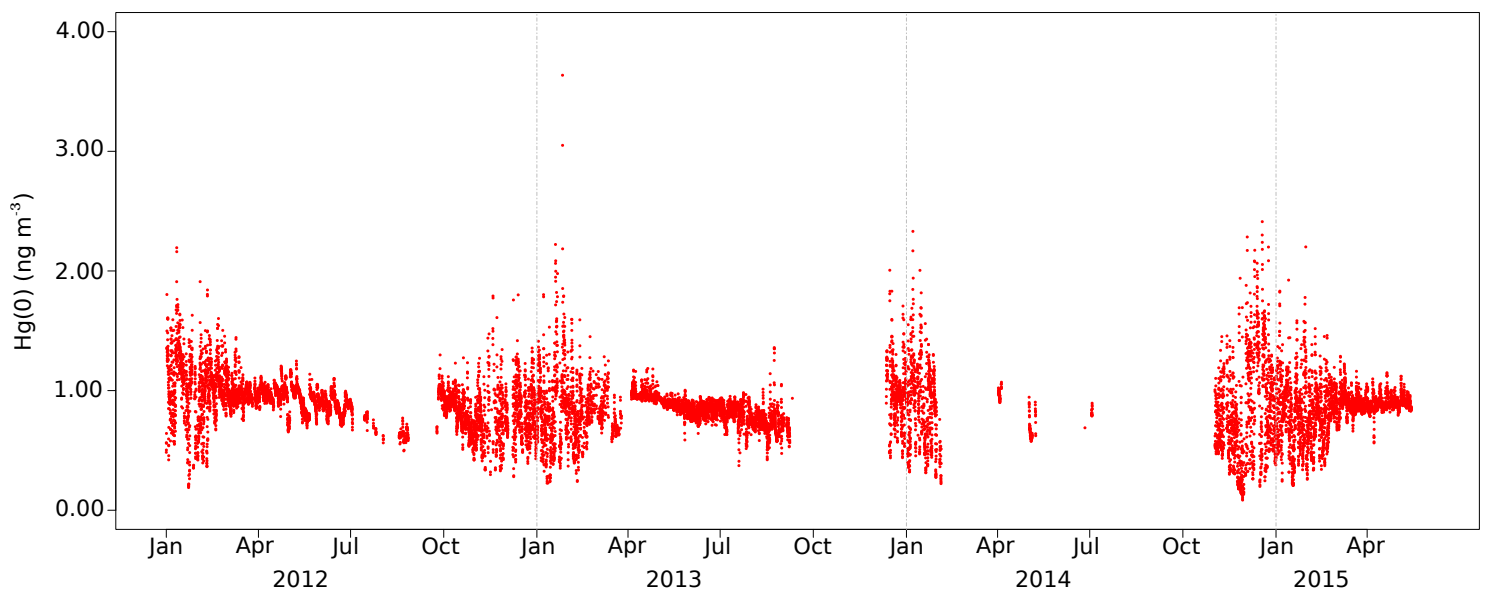

Figure 2. Hourly averaged $\mathrm{Hg}(0)$ concentrations $\left(\mathrm{ng} \mathrm{m}^{-3}\right)$ measured at DDU from January 2012 to May 2015. Missing data are due to instrument failure or $\mathrm{QA} / \mathrm{QC}$ invalidation. $\mathrm{Hg}(0)$ concentrations were highly variable during the sunlit period as compared to wintertime (May-August) suggesting a photochemically induced reactivity at this period of the year.

\section{Results and discussion}

The record of atmospheric $\mathrm{Hg}(0)$ from January 2012 to May 2015 is displayed in Fig. 2. Hourly averaged $\mathrm{Hg}(0)$ concentrations ranged from 0.10 to $3.61 \mathrm{ng} \mathrm{m}^{-3}$, with an average value of $0.87 \pm 0.23 \mathrm{ng} \mathrm{m}^{-3}$ (mean \pm standard deviation). This mean annual $\mathrm{Hg}(0)$ concentration is in good agreement with the value of $0.93 \pm 0.19 \mathrm{ng} \mathrm{m}^{-3}$ (4-year average) reported by Pfaffhuber et al. (2012) at TR, but lower than the concentration of $1.06 \pm 0.24 \mathrm{ng} \mathrm{m}^{-3}$ (12-month average) reported by Ebinghaus et al. (2002) at NM. While the same device was used at the three stations, the measurements may target different mercury species depending on their configuration (e.g., heated/unheated sample line). The difference between total gaseous mercury and $\mathrm{Hg}(0)$ data can be rather substantial since gaseous oxidized mercury $(\mathrm{Hg}(\mathrm{II}))$ concentrations of up to $\sim 0.30 \mathrm{ng} \mathrm{m}^{-3}$ were reported in spring/summer at several coastal Antarctic stations (Sprovieri et al., 2002; Temme et al., 2003; Brooks et al., 2008b). To allow a more accurate comparison of data available at the various Antarctic stations, more harmonized sampling protocols are needed. Seasonal boundaries have been defined as follows: summer refers to November-February, fall to March-April, winter to May-August, and spring to September-October. Though being arbitrary, this dissection was done by considering the time period over which the halogen chemistry (September-October) or the $\mathrm{OH} / \mathrm{NO}_{x}$ chemistry (November-February) is dominant at DDU (see Sect. 3.1.2 and 3.2.2). The mechanisms which cause the seasonal variation of $\operatorname{Hg}(0)$ concentrations are discussed in the following sections.

\subsection{From winter darkness to spring sunlight}

\subsubsection{Continental outflow and advection from lower latitudes in winter}

A gradual $20 \%$ decrease in $\operatorname{Hg}(0)$ concentrations from $0.89 \pm 0.09$ in average in May to $0.72 \pm 0.10 \mathrm{ng} \mathrm{m}^{-3}$ in August (Fig. 3a) was observed at DDU. Conversely, concentrations remained rather stable at NM and TR in winter with mean values of $1.15 \pm 0.08$ and $1.00 \pm 0.07 \mathrm{ng} \mathrm{m}^{-3}$, respectively (Ebinghaus et al., 2002; Pfaffhuber et al., 2012). Pfaffhuber et al. (2012) suggested that this stability of $\mathrm{Hg}(0)$ concentrations at TR is related to a lack of oxidation processes during the polar night.

A local reactivity at DDU - absent at other coastal stations - seems unlikely. Angot et al. (2016) showed evidence of a gradual $30 \%$ decrease of $\mathrm{Hg}(0)$ concentrations at DC at the same period of the year (Fig. 3a), probably due to a gas-phase oxidation, heterogeneous reactions, or dry deposition of $\operatorname{Hg}(0)$ onto the snowpack. Since the decreasing trend observed in winter is less pronounced at DDU than at DC, it most likely results from reactions occurring within the shallow boundary layer on the Antarctic plateau, subsequently transported toward the coastal margins by katabatic winds. This assumption is supported by the HYSPLIT model simulations showing prevalence in winter $(62 \pm 23 \%)$ of air masses originating from the Antarctic plateau reaching DDU (Fig. 4). The export of inland air masses towards the coastal regions is not uniform across Antarctica and is concentrated in a few locations - "confluence zones" - such as the Amery Ice Shelf region, the area near Adélie Land at $142^{\circ}$, the broad region upslope from the Ross Ice Shelf, and the eastern side of the Antarctic Peninsula at $\sim 60^{\circ} \mathrm{W}$ (Fig. 1) (Parish and Bromwich, 1987, 2007). Given its geographic location, DDU in Adélie Land lies close to a confluence zone explaining 


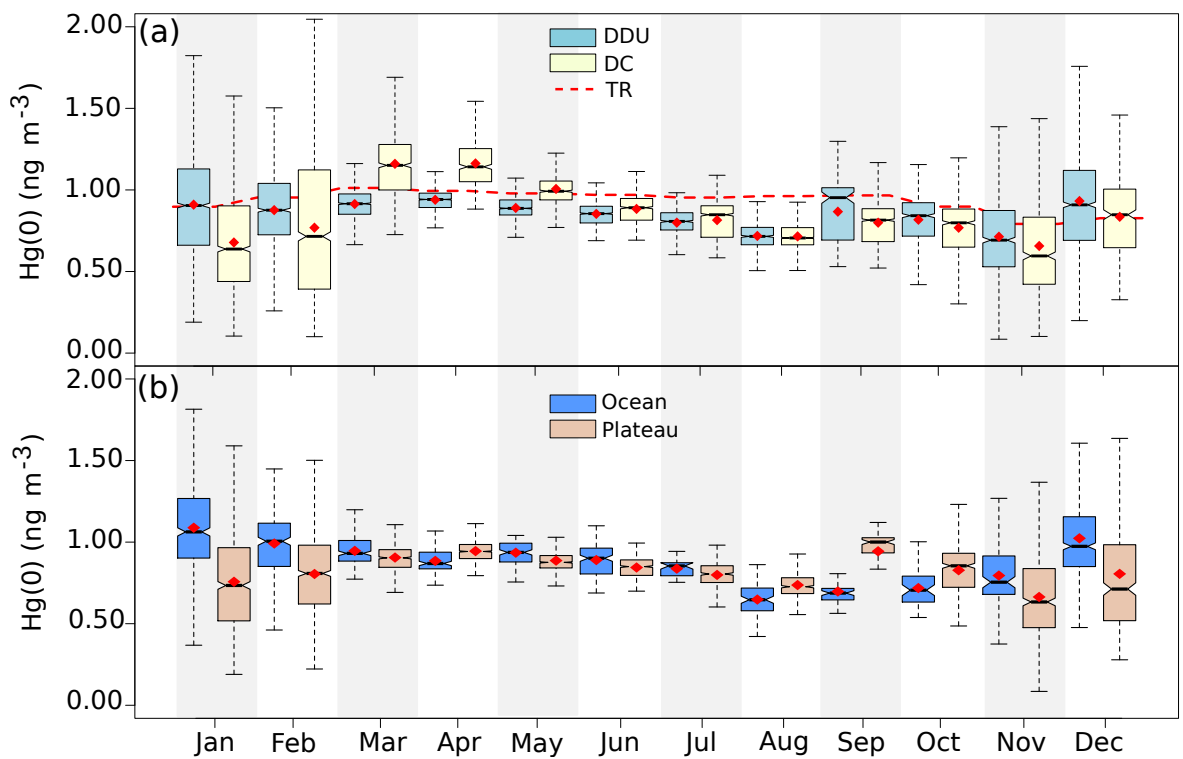

Figure 3. Box and whisker plot presenting the monthly $\mathrm{Hg}(0)$ concentration distribution (a) from all the data collected at DDU and DC along with the monthly mean recorded at TR, and (b) from all the data collected at DDU associated with air masses originating from the ocean or the Antarctic plateau according to the HYSPLIT simulations. Red diamond: mean, bottom and top of the box: first and third quartiles, band inside the box: median, ends of the whiskers: lowest (highest) datum still within the 1.5 interquartile range of the lowest (upper) quartile. Outliers are not represented.

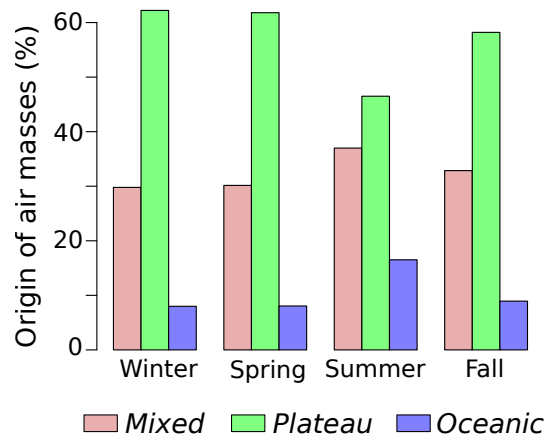

Figure 4. Mean percentage (\%) of continental/oceanic mixed air masses (pink), and of air masses originating from the Antarctic plateau (green) or the ocean (blue) according to the HYSPLIT model simulations in winter (May-August), spring (SeptemberOctober), summer (November-February), and fall (March-April).

the extent of the transport of air masses from the Antarctic plateau. Conversely, several studies showed that stations such as NM and HA are not significantly impacted by air masses originating from the Antarctic plateau (Helmig et al., 2007; Legrand et al., 2016b), consistently explaining why $\mathrm{Hg}(0)$ concentrations did not decrease at NM and TR throughout winter (Ebinghaus et al., 2002; Pfaffhuber et al., 2012).

Despite the overall decreasing trend in winter, $\operatorname{Hg}(0)$ concentrations sporadically exhibited abrupt increases when warm air masses from lower latitudes reached DDU. As illustrated by Fig. $5, \mathrm{Hg}(0)$ concentration for example in- creased from 0.72 ( 8 June 2012) to $1.10 \mathrm{ng} \mathrm{m}^{-3}$ (14 June 2012) with increasing temperature, and a significant positive correlation was found between the two parameters $(r=$ $0.88, p$ value $<0.0001$, Spearman test). This result is supported by an enhanced fraction of oceanic air masses reaching DDU at that time according to the HYSPLIT model simulations (Fig. 5d). Consistently, aerosol data gained in the framework of the French environmental observation service CESOA (http://www-lgge.obs.ujf-grenoble.fr/CESOA/spip. php?rubrique3) dedicated to the study of the sulfur cycle at middle and high southern latitudes indicate a mean sodium concentration of $450 \mathrm{ng} \mathrm{m}^{-3}$ between 10 and 14 June 2012 (not shown) instead of $112 \pm 62 \mathrm{ng} \mathrm{m}^{-3}$ over the other days of this month. It can be noted that the mean $\mathrm{Hg}(0)$ concentration in June 2012 was $0.95 \pm 0.04 \mathrm{ng} \mathrm{m}^{-3}$ at TR (Slemr et al., 2015), and $1.02 \pm 0.04 \mathrm{ng} \mathrm{m}^{-3}$ on Amsterdam Island $\left(37^{\circ} 48^{\prime} \mathrm{S}, 77^{\circ} 34^{\prime} \mathrm{E}\right.$, Angot et al., 2014). These values are consistent with the increase seen at DDU in air masses arriving from lower latitudes.

\subsubsection{The ice-covered ocean as a sink for $\mathrm{Hg}(0)$ in spring}

First discovered in the Arctic in 1995 (Schroeder et al., 1998), atmospheric mercury depletion events (AMDEs) have been subsequently observed after polar sunrise (mainly from early September to the end of October) at coastal or nearcoastal Antarctic stations at NM (Ebinghaus et al., 2002), TNB (Sprovieri et al., 2002), MM (Brooks et al., 2008b), and 


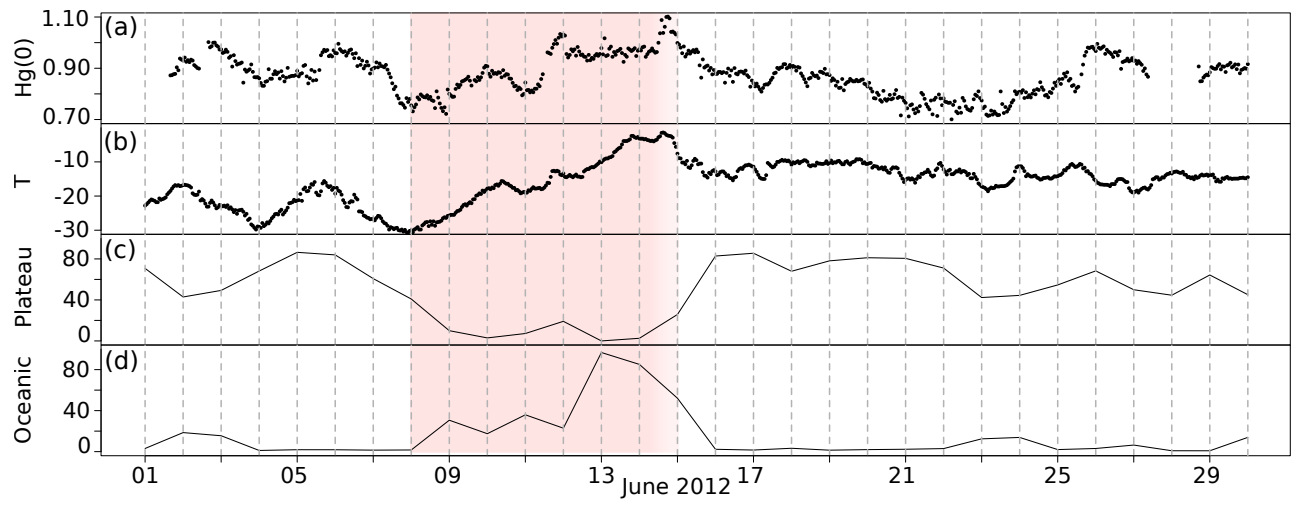

Figure 5. June 2012 variation of (a) $\mathrm{Hg}(0)$ concentration $\left(\mathrm{ng} \mathrm{m}^{-3}\right)$, (b) temperature $\left({ }^{\circ} \mathrm{C}\right)$, (c) daily averaged percentage $(\%)$ of air masses originating from the Plateau (HYSPLIT model simulations), and (d) daily averaged percentage (\%) of air masses originating from the ocean (HYSPLIT model simulations). From 8 to 14 June (period highlighted in red), both $\mathrm{Hg}(0)$ and temperature increased suggesting an advection of air masses from mid-latitudes, as confirmed by an elevated percentage of oceanic air masses.

TR (Pfaffhuber et al., 2012). These events, characterized by abrupt decreases of $\mathrm{Hg}(0)$ concentrations below $1.00 \mathrm{ng} \mathrm{m}^{-3}$ in the Arctic and $0.60 \mathrm{ng} \mathrm{m}^{-3}$ in Antarctica (Pfaffhuber et al., 2012), result from the oxidation of $\mathrm{Hg}(0)$ by reactive bromine species (e.g., Schroeder et al., 1998; Lu et al., 2001; Brooks et al., 2006; Sommar et al., 2007). At DDU, $\mathrm{Hg}(0)$ data covering the spring time period are scarce (Fig. 2) and we can just emphasize that the absence of $\mathrm{Hg}(0)$ drops in October 2012 tends to suggest that AMDEs, if exist, are not very frequent at DDU. Ozone depletion events (ODEs) are found to be less frequent and far less pronounced at DDU compared to other coastal stations such as NM and HA (Legrand et al., 2009, 2016b). Based on the oxygen and nitrogen isotope composition of airborne nitrate at DDU, Savarino et al. (2007) concluded to an absence of significant implication of $\mathrm{BrO}$ in the formation of nitric acid at this site, contrarily to what is usually observed in the Arctic where high levels of $\mathrm{BrO}$ are measured at polar sunise (Morin et al., 2008). All these observations are consistent with a less efficient bromine chemistry in East compared to West Antarctica due to a less sea-ice coverage, as also supported by GOME-2 satellite observations of the tropospheric $\mathrm{BrO}$ column (Theys et al., 2011; Legrand et al., 2016a). Additionally, air masses originating from the Antarctic plateau prevailed $(62 \pm 23 \%$, Fig. 4) in spring at DDU according to the HYSPLIT model simulations. This can also explain, to some extent, the lack of AMDE-observations at DDU.

Despite the absence of large AMDEs at DDU, springtime oceanic air masses were associated with low $\mathrm{Hg}(0)$ concentrations $\left(0.71 \pm 0.11 \mathrm{ng} \mathrm{m}^{-3}\right.$, see Fig. $\left.3 b\right)$. A slight but significant negative correlation was found between $\mathrm{Hg}(0)$ concentrations in spring and the daily averaged percentage of oceanic air masses reaching DDU $(r=-0.38$, $p$ value $=0.01$, Spearman test $)$ while a significant positive correlation was observed between springtime $\mathrm{Hg}(0)$ concentrations and $\mathrm{O}_{3}$ mixing ratios in these oceanic air masses
( $r$ up to $0.65, p$ value $<0.0001$, Spearman test). Therefore, though being not as pronounced as AMDEs observed at other coastal stations, we cannot rule out that the rather low background $\mathrm{Hg}(0)$ levels observed in spring at DDU are due to a weak effect of the bromine chemistry.

\subsection{High variability in $\mathrm{Hg}(0)$ concentrations in summer}

$\mathrm{Hg}(0)$ concentrations were highly variable during the sunlit period as compared to wintertime (Fig. 2). Figure 6 displays processes that may govern the atmospheric mercury budget at DDU in summer, as discussed in the following sections.

\subsubsection{Diurnal cycle of $\mathrm{Hg}(0)$ in ambient air}

Figure 7 displays the monthly mean diurnal cycle of $\operatorname{Hg}(0)$ concentrations at DDU. Undetected from March to October, a diurnal cycle characterized by a noon maximum was observed in summer (November to February). Interestingly, Pfaffhuber et al. (2012) did not observe any diurnal variation in $\operatorname{Hg}(0)$ concentrations at TR and there is no mention of a daily cycle at NM, TNB, and MM (Ebinghaus et al., 2002; Temme et al., 2003; Sprovieri et al., 2002; Brooks et al., 2008b).

$\mathrm{Hg}(0)$ concentrations at DDU were sorted according to wind speed and direction. With north at $0^{\circ}$, oceanic winds ranged from 270 to $110^{\circ} \mathrm{E}$, coastal winds from 110 to $130^{\circ} \mathrm{E}$, katabatic winds from 160 to $180^{\circ} \mathrm{E}$, and continental winds from 130 to $160^{\circ} \mathrm{E}$ and from 180 to $270^{\circ} \mathrm{E}$. Summertime $\mathrm{Hg}(0)$ concentrations exhibited a diurnal cycle regardless of wind speed and direction (Fig. 8). This result indicates that the observed diurnal cycle involves a local source of $\mathrm{Hg}(0)$ around midday which is, moreover, specific to DDU since the diurnal cycle is not observed at other coastal stations. 


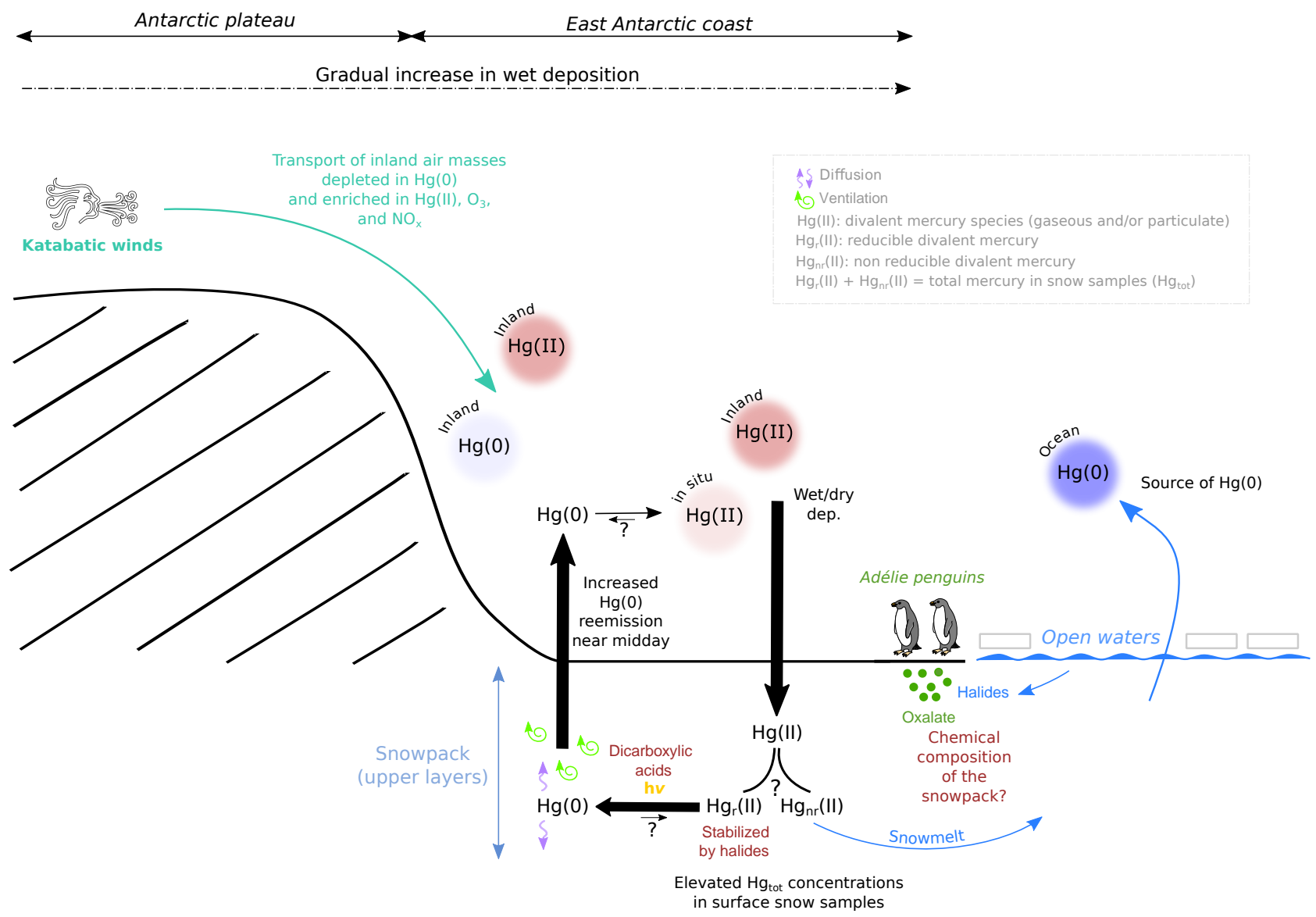

Figure 6. Schematic diagram illustrating the processes that may govern the mercury budget at DDU in summer. Katabatic winds transport inland air masses enriched in oxidants and $\mathrm{Hg}$ (II) toward the coastal margins. $\mathrm{Hg}$ (II) species deposit onto the snowpack by wet and dry processes leading to elevated concentrations of total mercury in surface snow samples. A fraction of deposited mercury can be reduced (the reducible pool, $\mathrm{Hg}_{\mathrm{r}}(\mathrm{II})$ ) in the upper layers of the snowpack and subsequently reemitted to the atmosphere as $\mathrm{Hg}(0)$. $\mathrm{Hg}(0) \mathrm{emission}$ from the snowpack maximizes near midday likely as a response to daytime heating. The chemical composition of the snowpack (halides, dicarboxylic acids) may influence the reduction rate of $\mathrm{Hg}$ (II) species within the snowpack. The ocean may be a net source of $\mathrm{Hg}(0)$ to the atmosphere.

\section{(a) Role of penguin emissions}

Large colonies of Adélie penguins nest on islands around DDU from the end of October to late February, with a total population estimated at 60000 individuals (Micol and Jouventin, 2001). Several studies highlighted that the presence of these large colonies at DDU in summer significantly disturbs the atmospheric cycle of several species including ammonium and oxalate (Legrand et al., 1998), carboxylic acids and other oxygenated volatile organic compounds (Legrand et al., 2012), and HCHO (Preunkert et al., 2013). In a study investigating sediment profiles excavated from ponds and catchments near penguin colonies in the Ross Sea region, Nie et al. (2012) measured high mercury content in penguin excreta (guano). Similarly, elevated total mercury concentrations were measured in ornithogenic soils (i.e., formed by accumulation of guano) of the Fildes and Ardley peninsulas of King George Island (De Andrade et al., 2012). When soil temperature rises above freezing in summer at DDU, oxalate is produced together with ammonium following the bacterial decomposition of uric acid in ornithogenic soils (Legrand et al., 1998 and references therein). Dicarboxylic acids such as oxalic acid were shown to promote the light-driven reduction of $\mathrm{Hg}(\mathrm{II})$ species in aqueous systems and ice (Gårdfeldt and Jonsson, 2003; Si and Ariya, 2008; Bartels-Rausch et al., 2011). Emissions of $\mathrm{Hg}(0)$ from snow-covered ornithogenic soils are expected to peak early and late summer - following the reduction of $\mathrm{Hg}$ (II) species in the upper layers of the snowpack -, as also seen in the oxalate concentrations at DDU (Legrand et al., 1998). Furthermore the rise of temperature at noon would strengthen $\mathrm{Hg}(0)$ emissions from ornithogenic soils, possibly contributing to the observed diurnal cycle from November to February. 

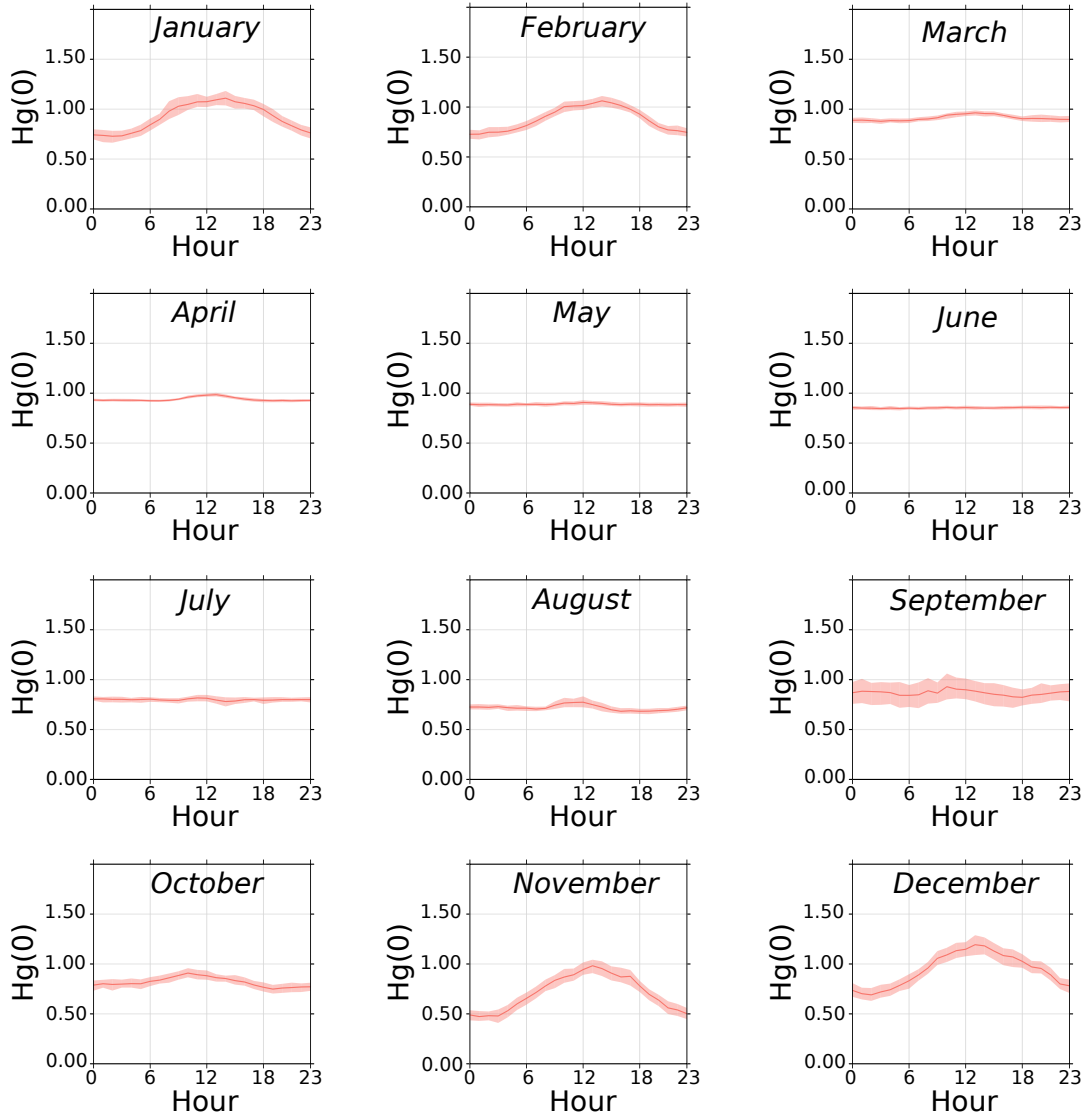

Figure 7. Monthly mean diurnal cycle of $\mathrm{Hg}(0)$ concentrations (in $\mathrm{ng} \mathrm{m}^{-3}$ ) along with the $95 \%$ confidence interval for the mean, calculated from all the data collected at DDU (January 2012-May 2015). Hours are in local time (UTC +10$)$. Hg(0) concentrations exhibit a strong diurnal cycle in summer (November-February).

\section{(b) Possible role of the "sea breeze"}

In summer, the surface wind direction sometimes changes from $120-160^{\circ} \mathrm{E}$ to North as temperature rises over midday (Pettré et al., 1993; Gallée and Pettré, 1998), giving birth to an apparent sea breeze. This phenomenon usually lasts half a day or less and air masses cannot be referred to as oceanic (see Sect. 2.2.3). Legrand et al. (2001, 2016b) observed increasing atmospheric dimethylsulfide (DMS) and chloride concentrations, respectively, during sea breeze events. However, our results indicate that $\mathrm{Hg}(0)$ concentrations did not tend to increase systematically with the occurrence of a sea breeze (e.g., Fig. 9).

\section{(c) Role of snowpack emissions}

Angot et al. (2016) reported a daily cycle in summer at DC with maximal $\mathrm{Hg}(0)$ concentrations around midday. This daily cycle atop the East Antarctic ice sheet was attributed to: (i) an intense oxidation of $\mathrm{Hg}(0)$ in the atmospheric boundary layer due to the high level of oxidants present there (Davis et al., 2001; Grannas et al., 2007; Eisele et al., 2008; Kukui et al., 2014), (ii) $\mathrm{Hg}$ (II) dry deposition onto the snowpack, and (iii) increased emission of $\operatorname{Hg}(0)$ from the snowpack around midday as a response to daytime heating following photoreduction of $\mathrm{Hg}$ (II) in the upper layers of the snowpack. Even if DDU is located on snow free bedrock for most of the summer season, the same mechanism could apply since the station is surrounded by vast snow-covered areas. However, such a dynamic cycle of deposition/reemission at the air-snow interface requires the existence of a summertime atmospheric reservoir of $\mathrm{Hg}(\mathrm{II})$ species nearby DDU. This question is addressed in the following section.

\subsubsection{Transport of reactive air masses from the Antarctic plateau}

Several previous studies pointed out that the major oxidants present in the summer atmospheric boundary layer at coastal Antarctic sites differ in nature from site to site: halogens chemistry prevails in the West, $\mathrm{OH} / \mathrm{NO}_{x}$ chemistry in the East (Legrand et al., 2009; Grilli et al., 2013). Measurements made at $\mathrm{HA}$ in summer indicate a $\mathrm{BrO}$ mixing ratio of 3 pptv (Saiz-Lopez et al., 2007), a $\mathrm{NO}_{2}$ mixing ratio of about 5 pptv (Bauguitte et al., 2012), and a $24 \mathrm{~h}$ average 


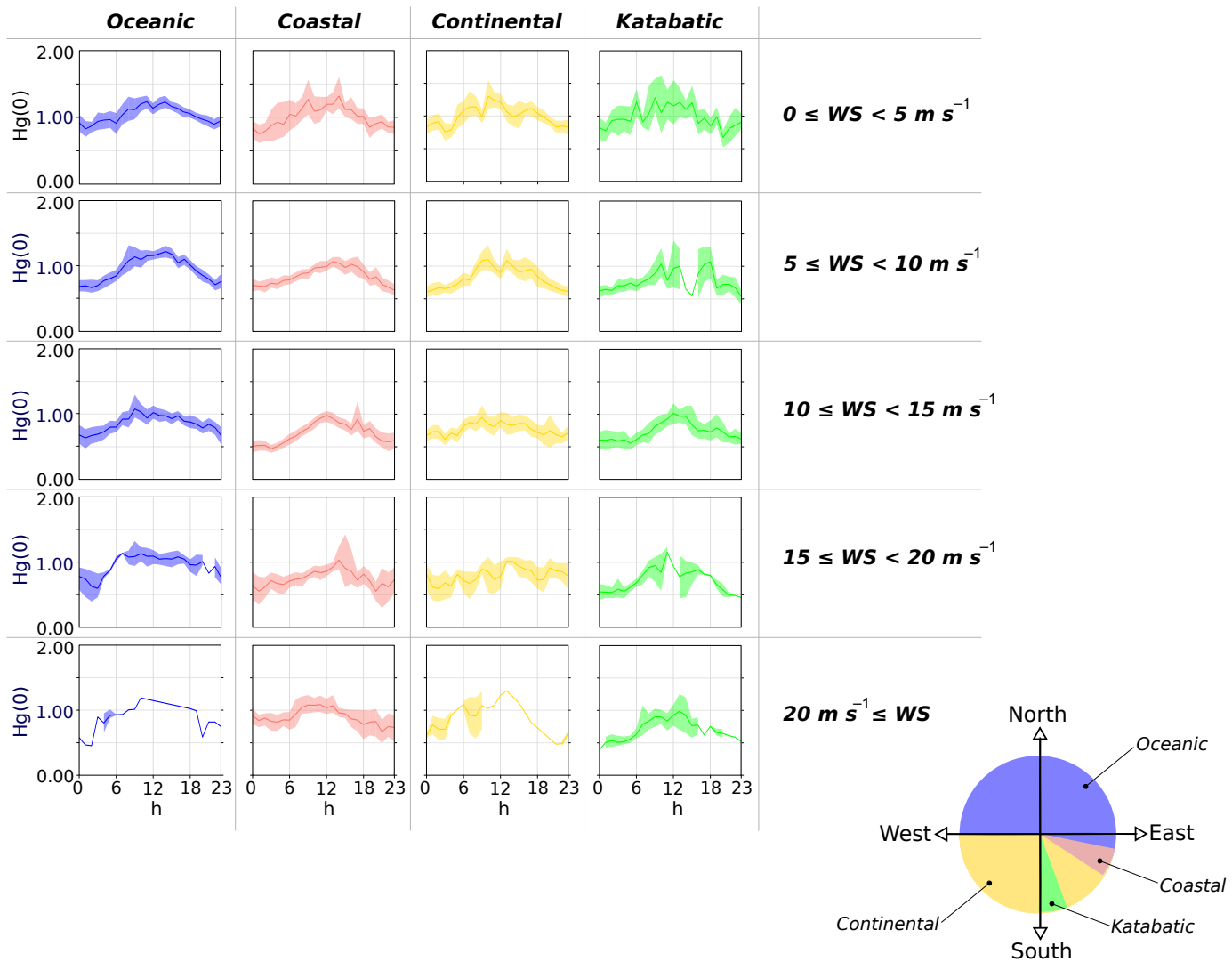

Figure 8. Summertime (November-February) mean diurnal cycle of $\mathrm{Hg}(0)$ concentrations (in $\mathrm{ng} \mathrm{m}^{-3}$ ), along with the $95 \%$ confidence interval for the mean, depending on wind direction and wind speed. With north at $0^{\circ}$, oceanic winds ranged from 270 to $110^{\circ}$, coastal winds from 110 to $130^{\circ}$, katabatic winds from 160 to $180^{\circ}$, and continental winds from 130 to $160^{\circ}$ and from 180 to $270^{\circ}$. Hours are in local time $(\mathrm{UTC}+10) . \mathrm{Hg}(0)$ concentrations exhibit a diurnal cycle regardless of wind speed and direction.

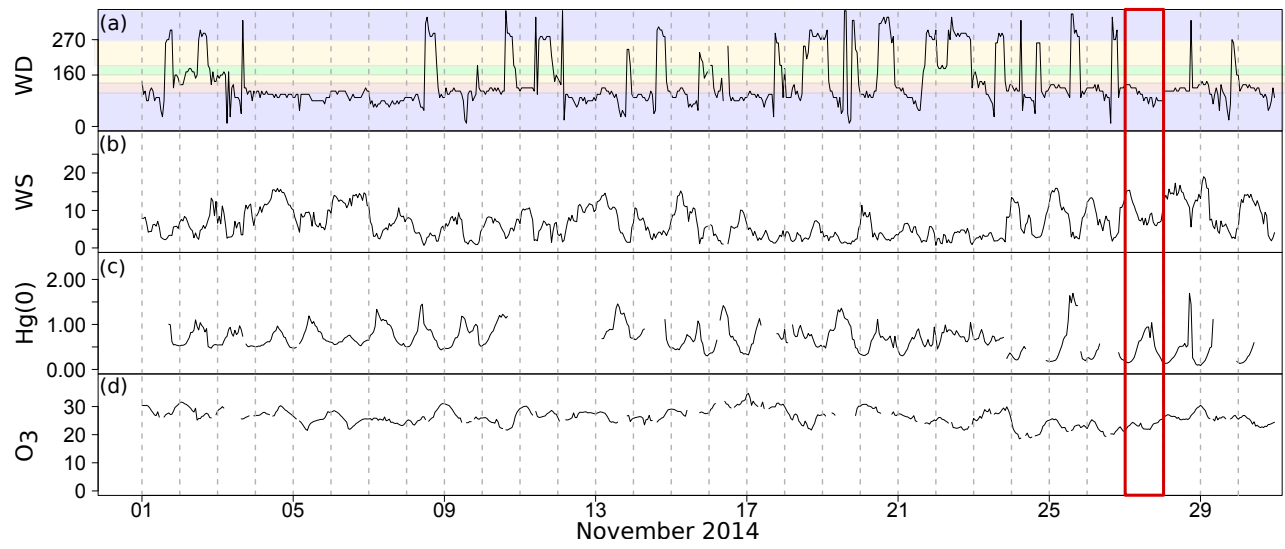

Figure 9. November 2014 variation of (a) wind direction (WD, in ${ }^{\circ}$ ), (b) wind speed (WS, in $\mathrm{m} \mathrm{s}^{-1}$ ), (c) $\mathrm{Hg}_{(0)}$ concentration (in ng $\mathrm{m}^{-3}$ ), and (d) $\mathrm{O}_{3}$ mixing ratio (in ppbv). With north at $0^{\circ}$, oceanic winds ranged from 270 to $110^{\circ}$ (purple), coastal winds from 110 to $130^{\circ}$ (pink), katabatic winds from 160 to $180^{\circ}$ (green), and continental winds from 130 to $160^{\circ}$ and from 180 to $270^{\circ}$ (yellow). On 27 November 2014 (period framed in red), a sea breeze is observed around midday: WD changes from $\sim 120-130$ to below $110^{\circ}$ while WS decreases. Both $\mathrm{Hg}(0)$ concentrations and $\mathrm{O}_{3}$ mixing ratios are not higher than during the previous days. 
value of $3.9 \times 10^{5}$ radicals $\mathrm{cm}^{-3}$ for $\mathrm{OH}$ (Bloss et al., 2007). Conversely, BrO levels are at least lower by a factor of 2 at DDU (Legrand et al., 2016a) and Grilli et al. (2013) reported a daily mean of 20 pptv for $\mathrm{NO}_{2}$ in summer at DDU while Kukui et al. (2012) reported a $24 \mathrm{~h}$ average value of $2.1 \times 10^{6}$ radicals cm ${ }^{-3}$ for $\mathrm{OH}$. Large $\mathrm{OH} / \mathrm{NO}_{x}$ concentrations at DDU compared to HA were attributed to the arrival of air masses originating from the Antarctic plateau where the $\mathrm{OH} / \mathrm{NO}_{x}$ chemistry is very efficient (Legrand et al., 2009; Kukui et al., 2012).

Goodsite et al. (2004) and Wang et al. (2014) suggested a two-step oxidation mechanism for $\mathrm{Hg}(0)$, favored at cold temperatures. The initial recombination of $\mathrm{Hg}(0)$ and $\mathrm{Br}$ is followed by the addition of a second radical (e.g., I, Cl, $\mathrm{BrO}$, $\mathrm{ClO}, \mathrm{OH}, \mathrm{NO}_{2}$, or $\mathrm{HO}_{2}$ ) in competition with the thermal dissociation of the $\mathrm{HgBr}$ intermediate. Using the rate constants calculated by Wang et al. (2014) for the reactions of $\mathrm{BrO}$, $\mathrm{NO}_{2}$, and $\mathrm{OH}$ with the $\mathrm{HgBr}$ intermediate, we found that $\mathrm{BrO}$ is the most efficient oxidant of $\mathrm{HgBr}$ at $\mathrm{HA}$ (lifetime of 1.9 against 2.2 min with $\mathrm{NO}_{2}$ and 11 days with $\mathrm{OH}$ ). At DDU the situation is reversed with a lifetime of the $\mathrm{HgBr}$ intermediate of 0.5 min with $\mathrm{NO}_{2}, 3.9$ min with $\mathrm{BrO}$ (assuming the presence of $1.5 \mathrm{pptv}$ of $\mathrm{BrO}$ in summer at DDU; Legrand et al., 2016a), and $2 \mathrm{~h}$ with $\mathrm{OH}$. These results suggest that the formation of $\mathrm{Hg}$ (II) species at DDU could be promoted by oxidants transported from the Antarctic plateau towards the coast.

In addition to oxidants, inland air masses may transport mercury species. Low $\mathrm{Hg}(0)$ concentrations $\left(0.76 \pm 0.30 \mathrm{ng} \mathrm{m}^{-3}\right)$ at DDU were associated with transport from the Antarctic plateau in summer (November to February, see Fig. 3b). A significant negative correlation was found in summer between $\operatorname{Hg}(0)$ concentrations and the daily averaged percentage of air masses originating from the Antarctic plateau $(r=-0.49, p$ value $<0.0001$, Spearman test). Brooks et al. (2008a) reported elevated concentrations of oxidized mercury species at SP in summer $\left(0.10-1.00 \mathrm{ng} \mathrm{m}^{-3}\right)$. Similarly, Angot et al. (2016) observed low $\operatorname{Hg}(0)$ concentrations at the same period of the year at $\mathrm{DC}\left(0.69 \pm 0.35 \mathrm{ng} \mathrm{m}^{-3}\right.$, i.e., $\sim 25 \%$ lower than at NM, TNB and MM). Angot et al. (2016) also reported the occurrence of multi-day to week-long $\mathrm{Hg}(0)$ depletion events (mean $\mathrm{Hg}(0)$ concentration $\sim 0.40 \mathrm{ng} \mathrm{m}^{-3}$ ) likely due to a stagnation of air masses above the plateau triggering an accumulation of oxidants within the shallow boundary layer. These observations indicate that inland air masses reaching DDU in summer are depleted in $\operatorname{Hg}(0)$ and enriched in $\mathrm{Hg}$ (II).

\section{Transect from central to coastal Antarctica}

The $\mathrm{Hg}_{\text {tot }}$ concentration of snow samples collected in summer 2009 between DC and DDU (see Sect. 2.2.2) ranged from 4.2 to $194.4 \mathrm{ng} \mathrm{L}^{-1}$ (Fig. 10). The closest sample from DC exhibited a $\mathrm{Hg}_{\text {tot }}$ concentration of $60.3 \pm 8.1 \mathrm{ng} \mathrm{L}^{-1}$

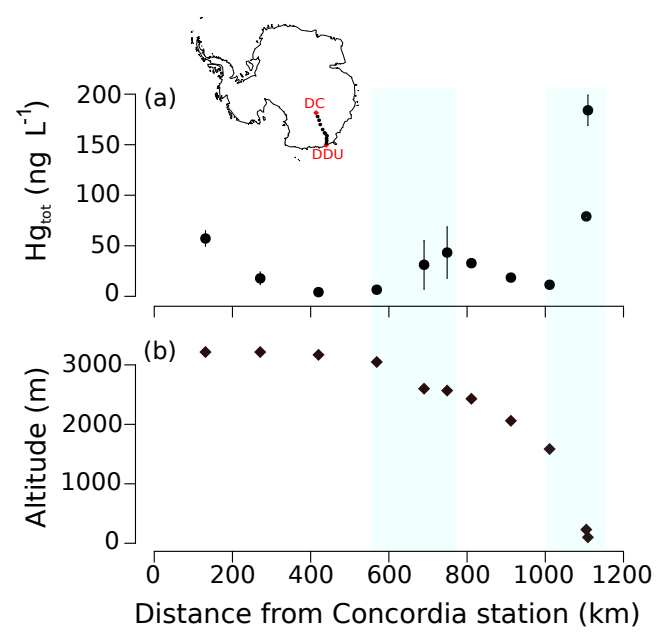

Figure 10. (a) Total mercury concentration in surface snow samples ( $\mathrm{Hg}_{\text {tot }}$ in $\mathrm{ng} \mathrm{L}^{-1}$ ) along with standard deviation and (b) altitude (m) vs. distance from Concordia station (DC) during the traverse from $\mathrm{DC}$ to DDU. $\mathrm{Hg}_{\text {tot }}$ concentrations increased in areas highlighted in blue, characterized by steeper slopes and higher snow accumulation values. All samples were analyzed in replicates of three. Standard deviation is frequently smaller than the width of the dots.

$(n=3)$, in very good agreement with concentrations found in surface snow samples collected in summer at DC (up to $73.8 \pm 0.9 \mathrm{ng} \mathrm{L}^{-1}$, Angot et al., 2016). As illustrated by Fig. $10, \mathrm{Hg}_{\text {tot }}$ concentrations increased between $600-800$ and $1000-1100 \mathrm{~km}$ from DC in areas characterized by steeper slopes and higher snow accumulation values. Several studies reported a gradual increase in snow accumulation from DC toward the coast (Magand et al., 2007; Verfaillie et al., 2012; Favier et al., 2013), in good agreement with a gradual increase in humidity (Bromwich et al., 2004). These results suggest that the wet deposition of $\mathrm{Hg}$ (II) species was enhanced near the coast, resulting in elevated $\mathrm{Hg}_{\text {tot }}$ concentrations in surface snow samples. Additionally, the presence of halides such as chloride in snow can reduce the reduction rate of deposited $\mathrm{Hg}$ (II) species by competing with the complexation of $\mathrm{Hg}(\mathrm{II})$ with dicarboxylic acids (Si and Ariya, 2008) resulting in higher $\mathrm{Hg}_{\text {tot }}$ concentrations in coastal snowpacks (Steffen et al., 2014). It is worth noting that the $\mathrm{Hg}_{\text {tot }}$ concentrations between DC and DDU were higher than the values measured in summer along other expedition routes in East Antarctica. Han et al. (2011) measured very low $\mathrm{Hg}_{\text {tot }}$ concentrations $\left(<0.4-10.8 \mathrm{pg} \mathrm{g}^{-1}\right)$ along a $\sim 1500 \mathrm{~km}$ transect in east Queen Maud Land, and $\mathrm{Hg}_{\text {tot }}$ concentrations ranged from 0.2 to $8.3 \mathrm{ng} \mathrm{L}^{-1}$ along a transect from $\mathrm{ZG}$ to DA (Fig. 1) (Li et al., 2014). Unfortunately none of the samples collected during these two traverses were truly coastal - the most seaward samples were collected at altitudes of 948 and $622 \mathrm{~m}$, respectively - preventing a direct comparison with the concentration measured near DDU. The mean $\mathrm{Hg}_{\text {tot }}$ concentration of $67 \pm 21 \mathrm{ng} \mathrm{L}^{-1}$ reported by Brooks et al. (2008b) 
at MM is the only truly coastal value available in Antarctica and is lower than the value reported here near DDU.

The advection of inland air masses enriched in both oxidants and $\mathrm{Hg}$ (II) likely results in the build-up of an atmospheric reservoir of $\mathrm{Hg}$ (II) species at DDU - as confirmed by elevated $\mathrm{Hg}_{\text {tot }}$ concentrations in surface snow samples -, confirming the hypothesis of a dynamic cycle of deposition/reemission at the air-snow interface.

\subsubsection{The ocean as a source of $\operatorname{Hg}(0)$}

DDU is located on a small island with open ocean immediately around from December to February. It should be noted that during summers 2011/2012, 2012/2013, and 2013/2014, areas of open waters were observed but with a significant unusual large amount of sea ice. Sea ice maps can be obtained from http://www.iup.uni-bremen.de:8084/amsr2data/ asi_daygrid_swath/s6250/(Spreen et al., 2008).

According to Fig. $3 \mathrm{~b}, \mathrm{Hg}(0)$ concentrations in oceanic air masses were elevated from December to February $\left(1.04 \pm 0.29 \mathrm{ng} \mathrm{m}^{-3}\right)$, and a significant positive correlation was found between $\mathrm{Hg}(0)$ concentrations and the daily averaged percentage of oceanic air masses in summer $(r=0.50$, $p$ value $<0.0001$, Spearman test). While in winter the ice cover limited mercury exchange at the air-sea interface (Andersson et al., 2008) leading to the build-up of mercuryenriched waters, large emissions of $\mathrm{Hg}(0)$ from the ocean likely occurred in summer. According to Cossa et al. (2011), total mercury concentrations can be one order of magnitude higher in under-ice seawater than those measured in open ocean waters. The authors attributed this build-up of mercury-enriched surface waters to the massive algal production at basal sea ice in spring/summer triggering a large production of $\operatorname{Hg}(0)$, and to the mercury enrichment in brine during the formation of sea ice. Elevated $\mathrm{Hg}(0)$ concentrations in oceanic air masses are consistent with observations in the Arctic where $\operatorname{Hg}(0)$ concentrations in ambient air peak in summer due to oceanic evasion and snowmelt re-volatilization (Dastoor and Durnford, 2014). Additionally, evasion from meltwater ponds formed on the remaining sea ice and observed around the station may contribute to the increase in $\mathrm{Hg}(0)$ concentrations (Aspmo et al., 2006; Durnford and Dastoor, 2011).

\section{Implications}

\subsection{For coastal Antarctic ecosystems}

The reactivity of atmospheric mercury is unexpectedly significant in summer on the Antarctic plateau as evidenced by elevated $\mathrm{Hg}(\mathrm{II})$ and low $\mathrm{Hg}(0)$ concentrations (Brooks et al., 2008a; Dommergue et al., 2012; Angot et al., 2016). This study shows that katabatic/continental winds can transport this inland atmospheric reservoir toward the coastal margins where $\mathrm{Hg}(\mathrm{II})$ species tend to deposit due to increasing wet deposition (Fig. 10). However, the post-deposition dynamics of mercury and its ultimate fate in ecosystems remain unknown. Bargagli et al. (1993, 2005) showed evidence of enhanced bioaccumulation of mercury in soils, mosses, and lichens collected in ice-free areas around the Nansen Ice Sheet (Victoria Land, upslope from the Ross Ice Shelf), suggesting an enhanced deposition of mercury species. Interestingly, four large glaciers join in the Nansen Ice Sheet region and channel the downward flow of air masses from the Antarctic plateau toward Terra Nova Bay, generating intense katabatic winds. The monthly mean wind speed is about $16 \mathrm{~m} \mathrm{~s}^{-1}$ in this area (Bromwich, 1989). Along with an enhanced deposition of mercury during AMDEs, the wind might as well be responsible for the advection of inland air masses enriched in $\mathrm{Hg}$ (II) species as observed in our case study. As already pointed out by Bargagli et al. (2005), coastal Antarctic ecosystems may become a sink for mercury, especially in view of increasing anthropogenic emissions of mercury in Asia (Streets et al., 2009).

\subsection{For the cycle of atmospheric mercury in high southern latitudes}

The influence of the Antarctic continent on the global geochemical cycle of mercury remains unclear (Dommergue et al., 2010). This study shows that the reactivity observed on the Antarctic plateau (Brooks et al., 2008a; Dommergue et al., 2012; Angot et al., 2016) influences the cycle of atmospheric mercury at a continental scale, especially downstream of the main topographic confluence zones. The question is whether the katabatic airflow propagation over the ocean is important. According to Mather and Miller (1967), the katabatic flow draining from the Antarctic plateau merges with the coastal polar easterlies under the action of the Coriolis force. The near-surface flow takes the form of an anticyclonic vortex (King and Turner, 1997), limiting the propagation of katabatic flows over the ocean.

\section{Conclusion}

We presented here a 3.5-year record of $\mathrm{Hg}(0)$ concentrations at DDU: the first multi-year record on the East Antarctic coast. Our observations reveal a number of differences with other costal or near coastal Antarctic records. In winter, observations showed a gradual $20 \%$ decrease in $\mathrm{Hg}(0)$ concentrations from May to August, a trend never observed at other coastal sites. This is interpreted as a result of reactions occurring within the shallow boundary layer on the Antarctic plateau, subsequently efficiently transported at that site by katabatic winds. In summer, the advection of inland air masses enriched in oxidants and $\mathrm{Hg}$ (II) species likely results in the build-up of an atmospheric reservoir of $\mathrm{Hg}$ (II) species at DDU, at least partly explaining the elevated (up to $\left.194.4 \mathrm{ng} \mathrm{L}^{-1}\right) \mathrm{Hg}_{\text {tot }}$ concentrations measured in surface snow 
samples near the station during a traverse between DC and DDU. Additionally, $\mathrm{Hg}(0)$ concentrations in ambient air exhibited a diurnal cycle in summer at DDU - phenomenon never observed at other coastal Antarctic stations. Several processes may contribute to this diurnal cycle, including a local chemical exchange at the air-snow interface in the presence of elevated levels of $\mathrm{Hg}$ (II) species in ambient air, and emissions from ornithogenic soils present at the site. Our data also highlight the fact that the Austral Ocean may be a net source for mercury in the summer. Even though AMDEs are likely very rare at DDU compared to other coastal stations, we cannot exclude that the sea-ice present offshore DDU at the end of winter influenced springtime $\mathrm{Hg}(0)$ levels. Finally, having shown that the reactivity observed on the Antarctic plateau influences the cycle of atmospheric mercury on the East Antarctic coast, this study raises concern for coastal Antarctic ecosystems there.

\section{Data availability}

Mercury data reported in this paper are available upon request at http://sdi.iia.cnr.it/geoint/publicpage/GMOS/gmos_ historical.zul (GMOS, 2016).

Acknowledgements. We thank the overwintering crew: S. Aguado, D. Buiron, N. Coillard, G. Dufresnes, J. Guilhermet, B. Jourdain, B. Laulier, S. Oros, and A. Thollot. We also gratefully acknowledge M. Barret for the development of a QA/QC software program, Météo France for the meteorological data, and Susanne Preunkert who helped to validate contamination-free ozone data. This work contributed to the EU-FP7 project Global Mercury Observation System (GMOS - www.gmos.eu) and has been supported by a grant from Labex OSUG@2020 (Investissements d'avenir - ANR10 LABX56), and the Institut Universitaire de France. Logistical and financial support was provided by the French Polar Institute IPEV (Program 1028, GMOstral).

Edited by: N. Pirrone

\section{References}

Andersson, M. E., Sommar, J., Gårdfeldt, K., and Linfqvist, O.: Enhanced concentrations of dissolved gaseous mercury in the surface waters of the Arctic Ocean, Mar. Chem., 110, 190-194, 2008.

Angot, H., Barret, M., Magand, O., Ramonet, M., and Dommergue, A.: A 2-year record of atmospheric mercury species at a background Southern Hemisphere station on Amsterdam Island, Atmos. Chem. Phys., 14, 11461-11473, doi:10.5194/acp14-11461-2014, 2014.

Angot, H., Magand, O., Helmig, D., Ricaud, P., Quennehen, B., Gallée, H., Del Guasta, M., Sprovieri, F., Pirrone, N., Savarino, J., and Dommergue, A.: New insights into the atmospheric mercury cycling in central Antarctica and implications on a continental scale, Atmos. Chem. Phys., 16, 8249-8264, doi:10.5194/acp-168249-2016, 2016.

Aspmo, K., Temme, C., Berg, T., Ferrari, C., Gauchard, P.-A., Faïn, X., and Wibetoe, G.: Mercury in the atmosphere, snow and melt water ponds in the north atlantic ocean during Arctic summer, Environ. Sci. Technol., 40, 4083-4089, 2006.

Bargagli, R., Battisti, E., Focardi, S., and Formichi, P.: Preliminary data on environmental distribution of mercury in northern Victoria Land, Antarctica, Antarct. Sci., 5, 3-8, 1993.

Bargagli, R., Agnorelli, C., Borghini, F., and Monaci, F.: Enhanced deposition and bioaccumulation of mercury in antarctic terrestrial ecosystems facing a coastal polynya, Environ. Sci. Technol., 39, 8150-8155, 2005.

Bartels-Rausch, T., Krysztofiak, G., Bernhard, A., Schläppi, M., Schwikowski, M., and Ammann, M.: Phototoinduced reduction of divalent mercury in ice by organic matter, Chemosphere, 82 , 199-203, 2011.

Bauguitte, S. J.-B., Bloss, W. J., Evans, M. J., Salmon, R. A., Anderson, P. S., Jones, A. E., Lee, J. D., Saiz-Lopez, A., Roscoe, H. K., Wolff, E. W., and Plane, J. M. C.: Summertime NO $x$ measurements during the CHABLIS campaign: can source and sink estimates unravel observed diurnal cycles?, Atmos. Chem. Phys., 12, 989-1002, doi:10.5194/acp-12-989-2012, 2012.

Bloss, W. J., Lee, J. D., Heard, D. E., Salmon, R. A., Bauguitte, S. J.-B., Roscoe, H. K., and Jones, A. E.: Observations of $\mathrm{OH}$ and $\mathrm{HO}_{2}$ radicals in coastal Antarctica, Atmos. Chem. Phys., 7, 4171-4185, doi:10.5194/acp-7-4171-2007, 2007.

Bromwich, D., Guo, Z., Bai, L., and Chen, Q.: Modeled antarctic precipitation. Part I: spatial and temporal variability, J. Climate, 17, 427-447, 2004.

Bromwich, D. H.: An extraordinary katabatic wind regime at Terra Nova Bay, Antarctica, Mon. Weather Rev., 117, 688-695, 1989.

Brooks, S., Saiz-Lopez, A., Skov, H., Lindberg, S. E., Plane, J. M. C., and Goodsite, M. E.: The mass balance of mercury in the springtime arctic environment, Geophys. Res. Lett., 33, L13812, doi:10.1029/2005GL025525, 2006.

Brooks, S. B., Arimoto, R., Lindberg, S. E., and Southworth, G.: Antarctic polar plateau snow surface conversion of deposited oxidized mercury to gaseous elemental mercury with fractional long-term burial, Atmos. Environ., 42, 2877-2884, 2008a.

Brooks, S. B., Lindberg, S. E., Southworth, G., and Arimoto, R.: Springtime atmospheric mercury speciation in the McMurdo, Antarctica coastal region, Atmos. Environ., 42, 2885-2893, 2008b.

Chen, D., Hale, R. C., La Guardia, M. J., Luellen, D., Kim, S., and Geisz, H. N.: Hexabromocyclododecane flame retardant in Antarctica: research station as sources, Environ. Pollut., 206, 611-618, 2015.

Cossa, D., Heimbürger, L.-E., Lannuzel, D., Rintoul, S. R., Butler, E. C. V., Bowie, A. R., Averty, B., Watson, R. J., and Remenyi, T.: Mercury in the Southern Ocean, Geochim. Cosmochim. Ac., 75, 4037-4052, 2011.

D’Amore, F., Bencardino, M., Cinnirella, S., Sprovieri, F., and Pirrone, N.: Data quality through a web-based QA/QC system: implementation for atmospheric mercury data from the Global Mercury Observation System, Environmental Science: Processes \& Impacts, 17, 1482-1491, 2015. 
Dastoor, A. P. and Durnford, D. A.: Arctic ocean: is it a sink or a source of atmospheric mercury?, Environ. Sci. Technol., 48, 1707-1717, 2014.

Davis, D., Nowak, J. B., Chen, G., Buhr, M., Arimoto, R., Hogan, A., Eisele, F., Mauldin, L., Tanner, D., Shetter, R., Lefer, B., and McMurry, P.: Unexpected high levels of NO observed at South Pole, Geophys. Res. Lett., 28, 3625-3628, 2001.

De Andrade, R. P., Michel, R. F. M., Schaefer, C. E. G. R., Simas, F. N. B., and Windmöller, C. C.: Hg distribution and speciation in Antarctic soils of the Fildes and Ardley peninsulas, King George Island, Antarct. Sci., 24, 395-407, 2012.

Dommergue, A., Sprovieri, F., Pirrone, N., Ebinghaus, R., Brooks, S., Courteaud, J., and Ferrari, C. P.: Overview of mercury measurements in the Antarctic troposphere, Atmos. Chem. Phys., 10, 3309-3319, doi:10.5194/acp-10-3309-2010, 2010.

Dommergue, A., Barret, M., Courteaud, J., Cristofanelli, P., Ferrari, C. P., and Gallée, H.: Dynamic recycling of gaseous elemental mercury in the boundary layer of the Antarctic Plateau, Atmos. Chem. Phys., 12, 11027-11036, doi:10.5194/acp-1211027-2012, 2012

Draxler, R. R. and Rolph, G. D.: HYSPLIT (HYbrid Single-Particle Lagrangian Integrated Trajectory) Model access via NOAA ARL READY Website, NOAA Air Resources Laboratory, College Park, MD, available at: http://www.arl.noaa.gov/HYSPLIT.php (last access: 24 October 2015), 2013.

Dumarey, R., Temmerman, E., Dams, R., and Hoste, J.: The accuracy of the vapour injection calibration method for the determination of mercury by amalgamation/cold vapour atomic spectrometry, Anal. Chim. Acta, 170, 337-340, 1985.

Durnford, D. and Dastoor, A.: The behavior of mercury in the cryosphere: a review of what we know from observations, J. Geophys. Res., 116, D06305, doi:10.1029/2010JD014809, 2011.

Ebinghaus, R., Kock, H. H., Temme, C., Einax, J. W., Löwe, A. G., Richter, A., Burrows, J. P., and Schroeder, W. H.: Antarctic springtime depletion of atmospheric mercury, Environ. Sci. Technol., 36, 1238-1244, 2002.

Eisele, F., Davis, D. D., Helmig, D., Oltmans, S. J., Neff, W., Huey, G., Tanner, D., Chen, G., Crawford, J. H., Arimoto, R., Buhr, M., Mauldin, L., Hutterli, M., Dibb, J., Blake, D., Brooks, S. B., Johnson, B., Roberts, J. M., Wang, Y., Tan, D., and Flocke, F.: Antarctic tropospheric chemistry (ANTCI) 2003 overview, Atmos. Environ., 2008, 2749-2761, 2008.

Favier, V., Agosta, C., Parouty, S., Durand, G., Delaygue, G., Gallée, H., Drouet, A.-S., Trouvilliez, A., and Krinner, G.: An updated and quality controlled surface mass balance dataset for Antarctica, The Cryosphere, 7, 583-597, doi:10.5194/tc-7-5832013, 2013.

Gallée, H. and Pettré, P.: Dynamical constraints on katabatic wind cessation in Adélie Land, Antarctica, J. Atmos. Sci., 55, 17551770, 1998.

Gårdfeldt, K. and Jonsson, M.: Is biomolecular reduction of $\mathrm{Hg}$ (II) complexes possible in aqueous systems of environmental importance, J. Phys. Chem. A, 107, 4478-4482, 2003.

GMOS: Land-based monitoring sites, available at: http://sdi.iia. cnr.it/geoint/publicpage/GMOS/gmos_historical.zul, last access: 27 Februrary 2016.

Goodsite, M. E., Plane, J. M. C., and Skov, H.: A theoretical study of the oxidation of $\mathrm{Hg}^{0}$ to $\mathrm{HgBr}_{2}$ in the troposphere, Environ. Sci. Technol., 38, 1772-1776, 2004.
Grannas, A. M., Jones, A. E., Dibb, J., Ammann, M., Anastasio, C., Beine, H. J., Bergin, M., Bottenheim, J., Boxe, C. S., Carver, G., Chen, G., Crawford, J. H., Dominé, F., Frey, M. M., Guzmán, M. I., Heard, D. E., Helmig, D., Hoffmann, M. R., Honrath, R. E., Huey, L. G., Hutterli, M., Jacobi, H. W., Klán, P., Lefer, B., McConnell, J., Plane, J., Sander, R., Savarino, J., Shepson, P. B., Simpson, W. R., Sodeau, J. R., von Glasow, R., Weller, R., Wolff, E. W., and Zhu, T.: An overview of snow photochemistry: evidence, mechanisms and impacts, Atmos. Chem. Phys., 7, 43294373, doi:10.5194/acp-7-4329-2007, 2007.

Grilli, R., Legrand, M., Kukui, A., Méjean, G., Preunkert, S., and Romanini, D.: First investigations of $\mathrm{IO}, \mathrm{BrO}$, and $\mathrm{NO}_{2}$ summer atmospheric levels at a coastal East Antarctic site using modelocked cavity enhanced absorption spectroscopy, Geophys. Res. Lett., 40, 791-796, 2013.

Hale, R. C., Kim, S. L., Harvey, E., La Guardia, M. J., Mainor, T. M., Bush, E. O., and Jacobs, E. M.: Antarctic research bases: local sources of polybrominated diphenyl ether (PBDE) flame retardants, Environ. Sci. Technol., 42, 1452-1457, 2008.

Han, Y., Huh, Y., Hong, S., Hur, S. D., Motoyama, H., Fujita, S., Nakazawa, F., and Fukui, K.: Quantification of total mercury in Antarctic surface snow using ICP-SF-MS: spatial variation from the coast to Dome Fuji, Bulletin of Korean Chemical Society, 32, 4258-4264, 2011.

Helmig, D., Oltmans, S. J., Carlson, D., Lamarque, J.-F., Jones, A., Labuschagne, C., Anlauf, K., and Hayden, K.: A review of surface ozone in the polar regions, Atmos. Environ., 41, 5138-5161, 2007.

Jaffe, D. A., Prestbo, E., Swartzendruber, P., Weiss-Penzias, P., Kato, S., Takami, A., Hatakeyama, S., and Kajii, Y.: Export of atmospheric mercury from Asia, Atmos. Environ., 2005, 3029 3038, 2005.

King, J. C. and Turner, J.: Antarctic Meteorology and Climatology, Cambridge University Press, Cambridge, UK, 409 pp., 1997.

König-Langlo, G., King, J. C., and Pettré, P.: Climatology of the three coastal Antarctic stations Dumont d'Urville, Neumayer, and Halley, J. Geophys. Res., 103, 10935-10946, 1998.

Kukui, A., Legrand, M., Ancellet, G., Gros, V., Bekki, S., SardaEstève, R., Loisil, R., and Preunkert, S.: Measurements of $\mathrm{OH}$ and $\mathrm{RO}_{2}$ radicals at the coastal Antarctic site of Dumont d'Urville (East Antarctica) in summer 2010-2011, J. Geophys. Res., 117, D12310, doi:10.1029/2012JD017614, 2012.

Kukui, A., Legrand, M., Preunkert, S., Frey, M. M., Loisil, R., Gil Roca, J., Jourdain, B., King, M. D., France, J. L., and Ancellet, G.: Measurements of $\mathrm{OH}$ and $\mathrm{RO}_{2}$ radicals at Dome C, East Antarctica, Atmos. Chem. Phys., 14, 1237312392, doi:10.5194/acp-14-12373-2014, 2014.

Legrand, M., Ducroz, F., Wagenbach, D., Mulvaney, R., and Hall, J.: Ammonium in coastal Antarctic aerosol and snow: role of polar ocean and penguin emissions, J. Geophys. Res., 103, 11043 11056, 1998.

Legrand, M., Sciare, J., Jourdain, B., and Genthon, C.: Subdaily variations of atmospheric dimethylsulfide, dimethylsulfoxide, methanesulfonate, and non-sea-salt sulfate aerosols in the atmospheric boundary layer at Dumont d'Urville (coastal Antarctica) during summer, J. Geophys. Res., 106, 14409-14422, 2001.

Legrand, M., Preunkert, S., Jourdain, B., Gallée, H., Goutail, F., Weller, R., and Savarino, J.: Year-round record of surface ozone at coastal (Dumont d'Urville) and inland (Concor- 
dia) sites in east antarctica, J. Geophys. Res., 114, D20306, doi:10.1029/2008JD011667, 2009.

Legrand, M., Gros, V., Preunkert, S., Sarda-Estève, R., Thierry, A.-M., Pépy, G., and Jourdain, B.: A reassessment of the budget of formic and acetic acids in the boundary layer at Dumont d'Urville (coastal Antarctica): the role of penguin emissions on the budget of serveral oxygenated volatile organic compounds, J. Geophys. Res., 117, D06308, doi:10.1029/2011JD017102, 2012.

Legrand, M., Yang, X., Preunkert, S., and Theys, N.: Year-round records of sea salt, gaseous, and particulate inorganic bromine in the atmospheric boundary layer at coastal (Dumont d'Urville) and central (Concordia) East Antarctic sites, J. Geophys. Res.Atmos., 121, 997-1023, doi:10.1002/2015JD024066, 2016a.

Legrand, M., Preunkert, S., Savarino, J., Frey, M. M., Kukui, A., Helmig, D., Jourdain, B., Jones, A., Weller, R., Brough, N., and Gallée, H.: Inter-annual variability of surface ozone at coastal (Dumont d'Urville, 2004-2014) and inland (Concordia, 20072014) sites in East Antarctica, Atmos. Chem. Phys. Discuss., doi:10.5194/acp-2016-95, in review, 2016b.

Li, C., Kang, S., Shi, G., Huang, J., Ding, M., Zhang, Q., Zhang, L., Guo, J., Xiao, C., Hou, S., Sun, B., Qin, D., and Ren, J.: Spatial and temporal variations of total mercury in Antarctic snow along the transect from Zhongshan station to Dome A, Tellus, 66, 25152, doi:10.3402/tellusb.v66.25152, 2014.

Lin, C.-J. and Pehkonen, S. O.: The chemistry of atmospheric mercury: a review, Atmos. Environ., 33, 2067-2079, 1999.

Lindberg, S. E. and Stratton, W. J.: Atmospheric mercury speciation: concentrations and behavior of reactive gaseous mercury in ambient air, Environ. Sci. Technol., 32, 49-57, 1998.

Lindberg, S. E., Bullock, R., Ebinghaus, R., Engstrom, D., Feng, X., Fitzgerald, W. F., Pirrone, N., Prestbo, E., and Seigneur, C.: A synthesis of progress and uncertainties in attributing the sources of mercury in deposition, Ambio, 36, 19-32, 2007.

Lindqvist, O. and Rodhe, H.: Atmospheric mercury - a review, Tellus, 37B, 136-159, 1985.

Lu, J. Y., Schroeder, W. H., Barrie, L. A., Steffen, A., Welch, H. E., Martin, K., Lockhart, L., Hunt, R. V., Boila, G., and Richter, A.: Magnification of atmospheric mercury deposition to polar regions in springtime: the link to tropospheric ozone depletion chemistry, Geophys. Res. Lett., 28, 3219-3222, 2001.

Magand, O., Genthon, C., Fily, M., Krinner, G., Picard, G., Frezzotti, M., and Ekaykin, A.: An up-to-date quality-controlled surface mass balance data set for the $90-180^{\circ} \mathrm{E}$ Antarctica sector and 1950-2005 period, J. Geophys. Res., 112, D12106, doi:10.1029/2006JD007691, 2007.

Mather, K. B. and Miller, G. S.: The problem of the katabatic winds on the coast of Terre Adélie, Polar Rec., 13, 425-432, 1967.

Micol, T. and Jouventin, P.: Long-term population trends in seven Antarctic seabirds at Pointe Géologie (Terre Adélie), Human impact compared with environmental change, Polar Biol., 24, 175$185,2001$.

Morin, S., Savarino, J., Frey, M. M., Yan, N., Bekki, S., Bottenheim, J. W., and Martins, J. M. F.: Tracing the origin and fate of $\mathrm{NO}_{x}$ in the Arctic atmosphere using stable isotopes, Science, 322, 730732, doi:10.1126/science.1161910, 2008.

Munthe, J., Sprovieri, F., Horvat, M., and Ebinghaus, R.: SOPs and QA/QC protocols regarding measurements of TGM, GEM, RGM, TPM and mercury in precipitation in cooperation with WP3, WP4 and WP5. GMOS deliverable 6.1, CNR-IIA, IVL, available at: http://www.gmos.eu (last access: 3 March 2014), 2011.

Nie, Y., Liu, X., Sun, L., and Emslie, S. D.: Effect of penguin and seal excrement on mercury distribution in sediments from the Ross Sea region, East Antarctica, Sci. Total Environ., 433, 132140, 2012.

Parish, T. R. and Bromwich, D. H.: The surface windfield over the Antarctic ice sheets, Nature, 328, 51-54, 1987.

Parish, T. R. and Bromwich, D. H.: Reexamination of the nearsurface airflow over the Antarctic continent and implications on atmospheric circulations at high southern latitudes, Mon. Weather Rev., 135, 1961-1973, 2007.

Pettré, P., Payan, C., and Parish, T. R.: Interaction of katabatic flow woth local thermal effects in a coastal region of Adelie Land, East Antarctica, J. Geophys. Res., 98, 10429-10440, 1993.

Pfaffhuber, K. A., Berg, T., Hirdman, D., and Stohl, A.: Atmospheric mercury observations from Antarctica: seasonal variation and source and sink region calculations, Atmos. Chem. Phys., 12, 3241-3251, doi:10.5194/acp-12-3241-2012, 2012.

Preunkert, S., Legrand, M., Pépy, G., Gallée, H., Jones, A., and Jourdain, B.: The atmospheric HCHO budget at Dumont d'Urville (East Antarctica): contribution of photochemical gasphase production versus snow emissions, J. Geophys. Res.Atmos., 118, 13319-13337, 2013.

Saiz-Lopez, A., Mahajan, A. S., Salmon, R. A., Bauguitte, S. J.-B., Jones, A. E., Roscoe, H. K., and Plane, J. M. C.: Boundary layer halogens in coastal antarctica, Science, 317, 348-351, 2007.

Savarino, J., Kaiser, J., Morin, S., Sigman, D. M., and Thiemens, M. H.: Nitrogen and oxygen isotopic constraints on the origin of atmospheric nitrate in coastal Antarctica, Atmos. Chem. Phys., 7, 1925-1945, doi:10.5194/acp-7-1925-2007, 2007.

Schroeder, W. H. and Munthe, J.: Atmospheric mercury - an overview, Atmos. Environ., 32, 809-822, 1998.

Schroeder, W. H., Anlauf, K. G., Barrie, L. A., Lu, J. Y., Steffen, A., Schneeberger, D. R., and Berg, T.: Arctic spingtime depletion of mercury, Nature, 394, 331-332, 1998.

Shirsat, S. V. and Graf, H. F.: An emission inventory of sulfur from anthropogenic sources in Antarctica, Atmos. Chem. Phys., 9, 3397-3408, doi:10.5194/acp-9-3397-2009, 2009.

Si, L. and Ariya, P. A.: Reduction of oxidized mercury species by dicarboxylic acids $\left(\mathrm{C}_{2}-\mathrm{C}_{4}\right)$ : kinetic and product studies, Environ. Sci. Technol., 42, 5150-5155, 2008.

Slemr, F., Angot, H., Dommergue, A., Magand, O., Barret, M., Weigelt, A., Ebinghaus, R., Brunke, E.-G., Pfaffhuber, K. A., Edwards, G., Howard, D., Powell, J., Keywood, M., and Wang, F.: Comparison of mercury concentrations measured at several sites in the Southern Hemisphere, Atmos. Chem. Phys., 15, 3125 3133, doi:10.5194/acp-15-3125-2015, 2015.

Sommar, J., Wängberg, I., Berg, T., Gårdfeldt, K., Munthe, J., Richter, A., Urba, A., Wittrock, F., and Schroeder, W. H.: Circumpolar transport and air-surface exchange of atmospheric mercury at Ny-Ålesund $\left(79^{\circ} \mathrm{N}\right)$, Svalbard, spring 2002, Atmos. Chem. Phys., 7, 151-166, doi:10.5194/acp-7-151-2007, 2007.

Spreen, G., Kaleschke, L., and Heygster, G.: Sea ice remote sensing using AMSR-E $89 \mathrm{GHz}$ channels, J. Geophys. Res., 113, C02S03, doi:10.1029/2005JC003384, 2008.

Sprovieri, F., Pirrone, N., Hedgecock, I. M., Landis, M. S., and Stevens, R. K.: Intensive atmospheric mercury measurements at Terra Nova Bay in antarctica during Novem- 
ber and December 2000, J. Geophys. Res., 107, 4722, doi:10.1029/2002JD002057, 2002.

Steffen, A., Schroeder, W., Bottenheim, J., Narayan, J., and Fuentes, J. D.: Atmospheric mercury concentrations: measurements and profiles near snow and ice surfaces in the Canadian Arctic during Alert 2000, Atmos. Environ., 36, 2653-2661, 2002.

Steffen, A., Douglas, T., Amyot, M., Ariya, P., Aspmo, K., Berg, T., Bottenheim, J., Brooks, S., Cobbett, F., Dastoor, A., Dommergue, A., Ebinghaus, R., Ferrari, C., Gardfeldt, K., Goodsite, M. E., Lean, D., Poulain, A. J., Scherz, C., Skov, H., Sommar, J., and Temme, C.: A synthesis of atmospheric mercury depletion event chemistry in the atmosphere and snow, Atmos. Chem. Phys., 8, 1445-1482, doi:10.5194/acp-8-1445-2008, 2008.

Steffen, A., Scherz, T., Oslon, M., Gay, D. A., and Blanchard, P.: A comparison of data quality control protocols for atmospheric mercury speciation measurements, J. Environ. Monitor., 14, 752765, doi:10.1039/c2em10735j, 2012.

Steffen, A., Lehnherr, I., Cole, A., Ariya, P. A., Dastoor, A., Durnford, D., Kirk, J., and Pilote, M.: Atmospheric mercury in the Canadian Arctic. Part I: A review of recent field measurements, Sci. Total Environ., 509-510, 3-15, doi:10.1016/j.scitotenv.2014.10.109, 2014.

Stohl, A.: Computation, accuracy and application of trajectories - a review and bibliography, Atmos. Environ., 32, 947-966, 1998.

Streets, D. G., Zhang, Q., and Wu, Y.: Projections of global mercury emissions in 2050, Environ. Sci. Technol., 43, 2983-2988, 2009.

Tekran: Tekran 2537 mercury monitor detection limit. Summary of known estimates, Tekran Instruments Corp., Toronto, ON, Canada, 2011.
Temme, C., Einax, J. W., Ebinghaus, R., and Schroeder, W. H.: Measurements of atmospheric mercury species at a coastal site in the antarctic and over the atlantic ocean during polar summer, Environ. Sci. Technol., 37, 22-31, 2003.

Theys, N., Van Roozendael, M., Hendrick, F., Yang, X., De Smedt, I., Richter, A., Begoin, M., Errera, Q., Johnston, P. V., Kreher, K., and De Mazière, M.: Global observations of tropospheric BrO columns using GOME-2 satellite data, Atmos. Chem. Phys., 11, 1791-1811, doi:10.5194/acp-11-1791-2011, 2011.

Verfaillie, D., Fily, M., Le Meur, E., Magand, O., Jourdain, B., Arnaud, L., and Favier, V.: Snow accumulation variability derived from radar and firn core data along a $600 \mathrm{~km}$ transect in Adelie Land, East Antarctic plateau, The Cryosphere, 6, 1345-1358, doi:10.5194/tc-6-1345-2012, 2012.

Wang, F., Saiz-Lopez, A., Mahajan, A. S., Gómez Martín, J. C., Armstrong, D., Lemes, M., Hay, T., and Prados-Roman, C.: Enhanced production of oxidised mercury over the tropical Pacific Ocean: a key missing oxidation pathway, Atmos. Chem. Phys., 14, 1323-1335, doi:10.5194/acp-14-1323-2014, 2014.

Yu, S., Mathur, R., Kang, D., Schere, K., and Tong, D.: A study of the ozone formation by ensemble back trajectory-process analysis using the Eta-CMAQ forecast model over the northeastern U.S. during the 2004 ICARTT period, Atmos. Environ., 43, 355363, 2009. 